\title{
A Community-based Survey of Household Food Insecurity and Associated Factors Among 2-6 Years Old Children in the Southeast of Iran
}

\section{Research}

Keywords:

Posted Date: December 10th, 2020

DOl: https://doi.org/10.21203/rs.3.rs-80686/v2

License: (c) (1) This work is licensed under a Creative Commons Attribution 4.0 International License. Read Full License 


\section{Abstract}

The authors have requested that this preprint be withdrawn due to author disagreement.

\section{Full Text}

The authors have withdrawn this preprint from Research Square. 